\title{
As metamorfoses em Macunaíma: (re)formulação da identidade nacional
}

\section{Cláudia Mentz Martins*}

\begin{abstract}
Resumo: A obra Macunaíma representa as propostas estéticas e temáticas modernistas das primeiras décadas do século $\mathrm{XX}$, sendo uma de suas características a presença de diferentes metamorfoses. As sofridas pelas personagens buscam dar uma origem aos elementos da fauna, da flora e/ou da civilização brasileira, dos astros e estrelas e dos objetos conhecidos pelo povo. Cabe sobretudo a Macunaíma, por ter o poder de alterar a si, ao outros seres e ao ambiente, a fundação da (nova) identidade nacional fixada pelo livro homônimo. Já as metamorfoses presentes no processo narrativo abordam outras mudanças, como as da voz narrativa, que afastam o texto da tradição literária brasileira. As metamorfoses na obra são fundamentais para a intenção do autor de (re)formular a identidade do País.
\end{abstract}

Palavras-chave: Macunaíma; Metamorfose; Identidade nacional

\begin{abstract}
Macunaíma represents the Modernist aesthetic proposals and themes of the first decades of the XX century. One of its characteristics is the presence of different metamorphoses. Those metamorphoses the characters go through intend to present an origin to the elements of the fauna, the flora and/or the Brazilian civilization, the heavenly bodies, stars and the objects known by the people. Since Macunaíma has the power to transform himself, the other beings and the environment, it is his role to build the foundation of the (new) national identity settled by the book with the same title. On the other hand, those metamorphoses that take place in the narrative process approach other transformations, such as the narrative voice, which deviate the text from the Brazilian literary tradition. The metamorphoses in the literary work are essential aspects to achieve the author's aim, namely, to (re)formulate the Country's identity.
\end{abstract}

Keywords: Macunaíma; Metamphoses; National Identity

O fenômeno da metamorfose é corrente nas narrativas da literatura ocidental, sendo encontrado já nas histórias da mitologia greco-latina como, por exemplo, nas zoomorfizações realizadas por Zeus para trair a esposa sem ser reconhecido por ela. As literaturas que sofreram a influência dessa tradição clássica - direta ou indiretamente, como é o caso da literatura brasileira - apresentam vários textos, escritos a partir do século XIX, que trazem a metamorfose. Aquelas encontradas em, por exemplo, Quincas Borba, de Machado de Assis, Grande sertão: veredas, de Guimarães Rosa, e Macunaíma, de Mário de Andrade, têm diferente sentido para a narrativa em que estão inseridas, mas todas abordam o processo da alteração da forma. Sobre a última obra citada, deteremos o olhar por julgar que nela a

\footnotetext{
Cláudia Mentz Martins é professora Colaborador Convidado do PPG-Letras da UFRGS e Bolsista CAPES/PRODOC na mesma Instituição.
} 
metamorfose assume um papel fundamental e privilegiado - o de tentar representar e (re)formular a identidade brasileira.

Ao analisar Macunaíma, não podemos esquecer que Mário de Andrade escreveu essa narrativa (de 1926, publicada em 1928) imbuído das idéias modernistas, muitas delas implicadas no desejo de recuperar e repensar a cultura nacional que assolou o País nas primeiras décadas do século $\mathrm{XX}^{1}$; nem de que há no Modernismo um sentido de dessacralização da identidade nacional percebido pelo desejo de se tratar o Diverso ${ }^{2}$ de tal forma que culturas de diferentes espaços dialoguem entre si. Em busca dos aspectos eminentemente nacionais, o autor utiliza o folclore, primeiro, por ser um pesquisador voltado ao assunto e, segundo, por nele encontrar material de cunho popular, primitivo, e, assim, brasileiro por excelência.

Lembramos que a identidade nacional não deve ser vista como um fim em si mesma, mas como o 'meio' em que entramos em contato com o outro. Sua busca é, pois, um processo que está em constante movimento. Como salienta Zila Bernd, a identidade é "como uma formação descontínua que se constrói através de sucessivos processos de reterriorialização e desreterriorialização", , sendo que o território é entendido como "o conjunto de representações que um indivíduo ou grupo tem de si próprio"4.

Macunaíma, a personagem título, por si só é uma lenda da região amazônica, a partir da qual o autor desenvolve toda a obra. Encontramos em Câmara Cascudo a explicação de que Macunaíma é uma entidade divina para diversas tribos latino-americanas, responsável pela criação de toda a existência terrena - à semelhança de Deus -, caracterizando-se também pela esperteza, maldade e alegria ${ }^{5}$. Percebemos que a personagem de Mário de Andrade

\footnotetext{
${ }^{1}$ Destaca-se aqui o Pau-Brasil e a Antropofagia. São de Oswald de Andrade o "Manifesto Pau-Brasil", de 1924, e o "Manifesto Antropófago", publicado em 1928, que tinha entre suas propostas a famosa paródia "Tupi or not tupi that is the question", a instigar o uso de aspectos da cultura brasileira. Cf. Gilberto Mendonça, 1976, p. 293300.

${ }^{2}$ Para Edouard Glissant (1981, p. 196) o Diverso significa "o esforço do espírito humano em direção a uma relação transversal, sem transcendência individualista; e necessita por os povos em relação entre si. Opõe-se ao conceito de Mesmo que se vincula com o da identidade que é fechada sobre si mesma, um discurso que se considera possuidor de uma única verdade".
}

${ }^{3}$ BERND, Zilá, 1992, p. 10.

${ }^{4}$ Idem, ibidem.

5 "Macunaima e não Macunaíma entidade divina para os macuxis, acavais, arecunas, taulipangues, indígenas caraíbas, a oeste do "plateau" da serra Roraima e Alto Rio Branco, na Guiana Brasileira. [...] A tradução da Bíblia para o idioma caraíba divulgou Macunaíma como sinônimo de deus. [...] Criador dos animais, vegetais e humanos, Macunaíma é gêmeo de Pia, vingadores de sua mãe, morta pelos tigres, filhos de Konaboáru, A Rã da Chuva, e que mora nas Plêiades [...] Com o passar dos tempos e convergência de tradições orais entre as tribos, interdependência cultural decorrente de guerras, viagens, permutas de produtos, Macunaíma foi-se tornando 
mantém as principais características do mito indígena, sendo, em função dela, através de sua ação ou de sua fala, que uma série de elementos da natureza ou objetos da modernidade passem a existir.

Seu nascimento é o ponto de partida da história e ocupa o primeiro parágrafo. Observamos que é junto à natureza mais afastada do homem civilizado que vem à luz e que é à noite, durante um sentimento de medo da mãe, que nasce. Não é uma criança índia de aparência idealizada, mas feia e já fruto da mestiçagem, porque também é negra:

No fundo do mato-virgem nasceu Macunaíma, herói de nossa gente. Era preto retinto e filho do medo da noite. Houve um momento em que o silêncio foi tão grande escutando o murmurejo do Uraricoera, que a índia tapanhumas pariu uma criança feia Essa criança é que chamaram de Macunaíma (ANDRADE, 1993, p. 9).

A fim de não haver dúvidas sobre a importância que o recém-nascido tem para o País, o narrador não só o anuncia como um herói - cujo pai não é mencionado, numa alusão à partenogênese $^{6}$-, como agrega o pronome possessivo 'nossa' ao substantivo 'gente', determinando sua relevância para o povo brasileiro.

Ainda no primeiro capítulo, o narrador mostra a capacidade do protagonista em metamorfosear-se na aparência que deseja para alcançar seus objetivos. A transformação em um 'lindo príncipe' ocorre para poder 'brincar' com Sofará, a mulher de Jiguê que é um dos irmãos do herói. Concluída a 'brincadeira', retorna à forma original. Também o poder que exerce sobre o meio é apresentando nesse capítulo quando, em função de um berreiro seu, "muitos pássaros caíram de susto no chão e se transformaram em pedra" (ANDRADE, 1993, p. 12).

Entretanto, quando a personagem troca de raça, passando da índio-negra para a branca, não pode reverter o processo, pois a água encantada - que estava na cova feita pelo pé de Sumé, no "tempo em que andava pregando o evangelho de Jesus pra indiada brasileira" (ANDRADE, 1993, p. 30) -, responsável pela transformação, deixa de existir. Nesse episódio, duas mutações são apresentadas: a primeira, mais do que uma amostra do potencial da natureza em transformar as coisas, temos a confirmação das mudanças que os brancos exerceram sobre os índios e negros, durante o período do descobrimento e da colonização. $\mathrm{O}$

herói, centro de um ciclo etiológico, zoológico, personagem essencial de aventuras e episódios reveladores do seu espírito inventivo, inesgotável de recursos mágicos, criando os homens de cera e depois de barro, esculpindo animais, transformando inimigos em pedras, que ainda guardam a forma primitiva. Tornou-se um misto de astúcia, maldade instintiva e natural, de alegria zombeteira e feliz.[...]”. Cf. Câmera Cascudo, 1998. p.530-531.

${ }^{6}$ Haroldo de Campos ([s.d], p. 107) considera essa partenogênese deformada e cômica, já que ela é um arremedo daquelas presentes em vários mitos e fábulas, que relatam uma origem miraculosa. 
processo de aculturação, iniciada por Sumé ${ }^{7}$, marca fisicamente os envolvidos; não apenas Macunaíma é metamorfoseado, também seus irmãos Jiguê e Maanape ficam com a feição alterada, sem possibilidade de voltarem a ser o que eram antes de tomarem contato com a 'herança' deixada pelo branco. A segunda alteração está ligada à formação das etnias existentes no País. Os três irmãos representam aqueles indivíduos que constituíram o Brasil, o branco, o índio e o negro. Todos integrantes de uma família unida ${ }^{8}$, afinal eles estão sempre juntos, seja na mata ou em São Paulo.

Não só a cor da pele de Macunaíma muda antes de ir para São Paulo. O seu porte físico também sofre alterações. Seu corpo, que parece ser o de uma criança, fica com a aparência de um adulto, com a ajuda de uma cotia, quando está fugindo do Currupira:

Então [a cotia] pegou na gamela cheia de caldo envenenado de aipim e jogou a lavagem no piá. Macunaíma fastou sarapantado mas só conseguiu livrar a cabeça, todo o resto do corpo se molhou. O herói deu um espirro e botou corpo. Foi desempenando crescendo fortificando e ficou do tamanho dum homem taludo. Porém a cabeça não molhada ficou pra sempre rombuda e com carinha enjoada de piá (ANDRADE, 1993, p.16).

$\mathrm{O}$ fato de não ter molhado a cabeça faz com que tenha um aspecto disforme e mantenha a feiúra do seu nascimento, além de permanecer com a mentalidade infantil. Com o branqueamento e o desenvolvimento do corpo, mais a retirada de sua consciência - que ele deixa a salvo das saúvas quando a coloca longe do chão- o herói pode ir a São Paulo e entrar em contato com o mundo moderno.

No início da narrativa, Macunaíma passa por várias metamorfoses que fazem com que assuma diferentes formas para seduzir a nova mulher de Jiguê, Iriqui. Primeiro, transforma-se em uma formiga; depois, num pé de urucum, planta a qual Iriqui não consegue resistir por ser muito faceira; e, finalmente, volta à forma humana para possui-la. Com essas mudanças, ele se identifica com a fauna e a flora brasileiras, e há o desenvolvimento da idéia de que o poder mágico da personagem está associado à sua atividade sexual.

Ao reforçar suas capacidades mágicas, o herói pode ressuscitar. A primeira vez que volta à vida acontece depois de seu encontro com o arqui-inimigo Piamã, que o havia matado e 'feito picadinho'. Com o auxílio do mano Maanape, que o retira da panela e o leva para a pensão, Macunaíma readquire a aparência humana. Ele só não escapa da morte, no final da narrativa, porque não o deseja. Novamente na mata - e após ter sido mutilado pela Uiara, cuja

\footnotetext{
${ }^{7}$ Sumé ou Zomé é uma figura pertencente à mitologia indígena brasileira, identificada pelos jesuítas como São Tomé. Seu surgimento é anterior ao descobrimento, tendo ensinado os índios a cultivarem o solo e a se comportarem moralmente. Por ter sido rejeitado, deixou o Brasil e se dirigiu às Índias, caminhando, segundo a lenda, sob as águas do oceano. Cf. Grande Enciclopédia Larousse, 1995, p. 5534.
}

${ }^{8}$ Cf. Regina Zilberman, 1994. p. 115-133. 
beleza não conseguiu resistir -, não acha mais graça nesta terra e sobe ao céu, sendo transformado pelo Pai do Mutum numa constelação nova, a Ursa Maior. Seu final é mediado pela dança folclórica do Bumba-meu-boi, em que a morte e a ressurreição do boi se ligam à devoração que o herói sofreu pelas piranhas.

A partir do final do capítulo III, vários seres, sobretudo femininos, que entram em contato com o herói, deixam de existir como humanos para se tornarem astros celestes. $\mathrm{O}$ primeiro indivíduo que passa por esse processo é Ci, a Mãe do Mato. Entristecida por ter causado involuntariamente a morte do filho que teve com Macunaíma, e depois de ter dado a esse a muiraquitã, ela vai ao céu e vira uma estrela, a Beta do Centauro ${ }^{9}$ :

a companheira de Macunaíma toda enfeitada ainda, tirou do colar uma muiraquitã famosa, deua pro companheiro e subiu pro céu por um cipó. É lá que Ci vive agora nos trinques passeando, liberta das formigas, toda enfeitada ainda, toda enfeitada de luz, virada numa estrela. É a Beta do Centauro (ANDRADE, 1993, p.22).

Capei transforma-se na Lua, após ter sido xingada e decapitada pelo herói. A boiúna se mostra rendida a Macunaíma, mas como ele tem medo dela, fugindo da cabeça sem corpo, ela passa a persegui-lo. Sem conseguir alcançá-lo, Capei se lamuria à iandu caranguejeira, pedindo ajuda para subir ao céu. Portanto, a existência do satélite terrestre deve-se a ação do herói:

Quando foi ali pela hora antes da madrugada a boiúna Capei chegou no céu. Estava gorducha de tanto fio comido e muito pálida do esforço. Todo o suor dela caia sobre a Terra em gotinhas de orvalho novo. Por causa do fio geado é que Capei é tão fria. Dantes Capei foi a boiúna mas agora é a cabeça da Lua lá no campo vasto do céu. Desde essa feita as caranguejeiras preferem fazer fio de noite (ANDRADE, 1993, p. 27).

Junto à recriação da lenda relativa à existência da Lua, da metamorfose da boiúna, temos a explicação para a característica das caranguejeiras só tecerem à noite, a saber: é este o horário mais favorável para fazerem seus fios, já que foi devido a eles que Capei tornou-se fria e não quente como Sol. A Capei, metamorfoseada em Lua, gera a temperatura ideal para o trabalho das aranhas que a ajudaram a se refugiar no céu.

Outras personagens femininas que passam a integrar o céu, depois de se envolverem com Macunaíma, são: (a) a filha de Piaimã, (b) Suzi e (c) Iriqui. A primeira, filha de Ceuci e de Piaimã, por ter ajudado o herói a fugir dos pais, é castigada por eles, que a expulsam de

\footnotetext{
${ }^{9}$ Para Maria Eneida de Souza (1999, p. 86-87), Ci é punida pela lógica mítica, representando sua subida ao céu o papel ambivalente da mulher diante do filho e de Macunaíma. Citando Koch-Grünberg, a autora aponta Ci como uma planta possuidora de um leite com propriedades que causam o sucesso dos homens na caça. Portanto, ela, como estrela e planta mágica, faz com que seu leite (ao mesmo tempo em que é o veneno para o filho) seja um remédio metafórico para Macunaíma, "visto que Ci deixa como herança a pedra muiraquitã, uma variante do leite mágico". A essa personagem feminina também cabe a força da narrativa: são as tentativas de Macunaíma em recuperar a pedra que $\mathrm{Ci}$ lhe deixou que fazem a história progredir.
} 
casa. Além disso, é transformada num corpo em constante movimento - "É uma cometa" (ANDRADE, 1993, p. 86).

A segunda, Suzi, ao ser expulsa pelo companheiro Jiguê do quarto que dividem com o irmão mais novo dele, por ela o ter traído com esse, agrega os piolhos, que sempre a acompanharam, na sua metamorfose: "Daí ela sorriu feliz. Captou sem contar todos os piolhos que restavam e eram muitos piolhos, atrelou-os a uma cadeira-de-balanço, sentou nela, os piolhos pularam e Suzi foi pro céu virada na estrela que pula. É uma zelação" (ANDRADE, 1993, p.98).

Já a terceira, Iriqui, depois de ter sido seduzida e abandonada pelo protagonista, quando esse parte para São Paulo, fica triste e sobe às alturas na hora em que o herói retorna à mata e brinca com a princesa e não com ela: "Iriqui ficou triste triste, bem triste, chamou seis araras canindés e subiu com elas pro céu, chorando luz virada numa estrela. As canindés amarelinhas também viraram estrelas. É o Setestrelo" (ANDRADE, 1993, p.115).

Nesses casos, as metamorfoses são uma punição às avessas às mulheres que se envolvem com Macunaíma, pois se elas perdem a forma humana, virando astros e habitando o céu - numa esfera superior a terra -, passam a ser admiradas por todos os homens que olham as estrelas. Não nos esquecendo que, ao final da rapsódia, o protagonista se junta a elas, nova e derradeiramente, também transformado numa constelação.

A mãe de Macunaíma é uma exceção, pois, apesar de ele também ser o responsável pela sua morte - ele imaginava estar matando uma veada parida -, a metamorfose dela resulta num cerro. Como mãe, entidade fértil, geradora de vidas, permanece ligada ao solo, relacionando-se à terra fecunda.

Outras personagens, que mantêm relação com Macunaíma, são transformadas em espécies da flora brasileira. $\mathrm{O}$ filho dele com $\mathrm{Ci}$, que morre envenenado ao ingerir o leite materno contaminado, é um exemplo. Cabe a essa criança transformar-se na planta do guaraná, bebida típica dos povos indígenas brasileiros, recriando essa lenda:

No outro dia quando Macunaíma foi visitar o túmulo do filho viu que nascera do corpo uma plantinha. Trataram dela com muito cuidado e foi o guaraná. Com as frutinhas piladas dessa planta é que a gente cura muita doença e se refresca durante os calorões de Vei, a Sol (ANDRADE, 1993, p.22).

Mesmo quando Macunaíma não está ligado à metamorfose, essa lhe é narrada, geralmente, pelo ser que sofreu o processo de mutação. Ao encontrar-se com Naipi, escuta-lhe sua história de amor com Titçatê e o castigo dos dois: ela foi transformada numa cascata bracejada pelo amado, que hoje é uma planta cujas pétalas roxas são o sangue congelado pelas águas dela. 
Encontramos ainda metamorfoses que são fruto da imaginação do herói, as quais conhecemos através da sua própria fala, como é o caso da origem do Cruzeiro do Sul. Ao contar a história para a existência da constelação, que é a transformação sofrida pelo Pai do Mutum - que "num tempo muito de dantes" já foi gente -, Macunaíma relata um dos trechos da obra em que o processo de metamorfose é bastante explorado. Inicialmente, Pai do Mutum é uma das identidades de Paui-Pódole, que procura se livrar do ataque do catimbozeiro CamãPabinque, que tenta caçá-lo ora metamorfoseado na tocadeira Ilangue, ora na tacuri Opala e finalmente na lavapés Megue. Com isso, Macunaíma não apenas utiliza o aspecto mágico das mutações, mas também recria uma lenda do folclore:

Meus senhores e minhas senhoras! Aquelas quatro estrelas lá é o Pai do Mutum! juro que é o Pai do Mutum, minha gente, que pára no campo vasto do céu!...

Minha gente! aquelas quatro estrelas não é Cruzeiro, que Cruzeiro nada! É o Pai do Mutum! É o Pai do Mutum! minha gente! É o Pai do Mutum, Pauí-Pódole que pára no campo vasto do Céu!... Tem mais não (ANDRADE, 1993, p.72-73).

Assim, ao estabelecer uma nova explicação para o surgimento da constelação, reformula o conhecimento popular. Além disso, faz com que as histórias esparsas do folclore brasileiro integrem Macunaíma, uma narrativa maior: a do próprio herói.

Há ainda as mutações para esclarecer o surgimento dos objetos modernos como o automóvel, que, na sua origem, segundo Macunaíma, era uma onça parda. Essa, para fugir de um tigre que enganou, foi alterando sua aparência. Durante a narração, a metamorfose pela qual a onça passa não é a de simples transformação, mas ocorre através da fusão do animal com outros elementos pertencentes à máquina, por exemplo, rodas e motor. Dessa metamorfose, também insetos fazem parte: vagalumões são engolidos pela 'bicha' para iluminar o caminho, à semelhança dos faróis.

O aeroplano, também um animal, tuiuiú, assume a forma de máquina para ajudar o herói a fugir dos apuros em que se envolve quando é preso por Piaimã, por brincar com a filha do gigante: "Logo o tuiuiú se transformou na máquina aeroplano, Macunaíma escanchou no aturiá vazio e ergueram vôo" (ANDRADE, 1993, p. 86).

As transformações que Jiguê sofre, quando está na cidade, são fruto da vontade do irmão caçula. Quando Macunaíma descobre que "os homens é que eram máquinas e as máquinas eram homens" (ANDRADE, 1993, p.33), cria uma fórmula que lhe permite transformar o primeiro, o homem, na máquina que melhor resolve seus problemas: "Virou Jiguê na máquina telefone, ligou pros cabarés encomendando lagostas e francesas" (ANDRADE, 1993, p.33). 
Ao longo dessas metamorfoses, que incorporam o real e o maravilhoso sem distanciamento, notamos que não existe uma regra para que elas aconteçam, isto é, as causas que as geram são as mais diferentes possíveis. Entretanto, a maioria das metamorfoses ocorre pelos entes envolvidos - humanos, entidades mágicas ou animais - terem se relacionado com o protagonista e, por causa disso, ora ganham a aparência de um prêmio, ora de uma punição a eles. Todavia, nos casos em que a ação de Macunaíma não é direta, geralmente é por sua voz que as demais metamorfoses são conhecidas. Assim, cabem também a ele essas transformações.

No texto, há mudanças relacionadas ao espaço da narrativa. A história começa na mata, passa pela cidade de São Paulo e termina no ambiente inicial, com o retorno dos irmãos. Tal como a personagem teve sua feição alterada, os locais por onde ela transita também mudam: do mais rústico e distante da civilização, ao mais moderno, o centro industrial e econômico do País. Desse modo, o protagonista assimila as diferenças existentes no território e conhece o Brasil. Macunaíma também se confirma como um herói, representante dos contos populares: ele parte de seu ambiente para buscar algo - a muiraquitã -, passa por um rito de passagem - a viagem a São Paulo -, e retorna com novos conhecimentos e sabedoria à terra de origem. Macunaíma, inclusive, leva para a floresta elementos da civilização paulista: o revólver Smith-Wesson, o relógio Patek e o casal de galinha Legone, aos quais dá novo significado ao mudar-lhes a utilidade, fazendo, dos dois primeiros, brincos para as orelhas. Contudo, ao contrário dos heróis que estão prontos para governar suas terras ao voltarem da incursão pelo mundo, o Imperator, desiludido e triste, abdica de fazê-lo ao chegar à mata.

$\mathrm{O}$ primeiro contato com a cidade grande é envolto em sentimentos de medo e curiosidade. Para compreender São Paulo, Macunaíma compara aspectos citadinos aos da mata, aos da sua cultura, fazendo com que esse centro urbano reduplique o seu lugar de origem, adquirindo nova forma:

Que mundo de bichos! que despropósito de papões roncando, mauaris juruparis sacis e boitatás nos atalhos nas socavas nas cordas dos morros furados por grotões [...] De-manhãzinha ensinaram que todos aqueles piados berros cuquiadas sopros roncos esturros não eram nada disso não, eram mas cláxons campainhas apitos buzinas e tudo era máquina. As onças pardas não eram onças pardas, se chamavam fordes hupmobiles chevrolés dodges mármons e eram máquinas. Os tamanduás os boitatás as inajás de curuatás de fumo, em vez eram caminhões bondes autobondes anúncios-luminosos relógios faróis rádios motocicletas telefones gorjetas postes chaminés... [...] De vez em quando [Macunaíma] estremecia (ANDRADE, 1993, p.3132).

Macunaíma, ao ir embora de São Paulo, deixa sua marca indelével nesse espaço, pois, com seus poderes, ele o metamorfoseia num grande bicho-preguiça. Isso vai de encontro às necessidades da cidade, o centro nevrálgico das transações comerciais, políticas, responsável 
pelo progresso e industrialização do País, um lugar que precisa de dinamicidade: "Então [Macunaíma] fez um caborge; sacudiu os braços no ar e virou a taba gigante num bicho preguiça todinho de pedra" (ANDRADE, 1993, p.107).

Com relação ao espaço, cabe ainda observarmos o que diz respeito à ruptura total das fronteiras provocadas pela personagem central. Ao passear pelo Brasil, elimina as delimitações estaduais, já que, com seu poder mágico, circula pelo País sem se preocupar com a geografia. Desse modo, reformula as idéias sobre a nação, uma vez que sua existência não conta como formada por vários Estados, mas por ser uma unidade territorial:

[Macunaíma e o tuiuiú aeroplano] Voaram sobre o chapadão mineiro de Urucuia, fizeram o circuito de Itapecerica e bateram pro Nordeste. Passando pelas dunas de Mossoró [...]

Depois que pulando a serra do Tombador no Mato Grosso deixaram pra esquerda as cochilhas de Sant'Ana do Livramento, o tuiuiú-aeroplano e Macunaíma subiram até o Telhado do Mundo, mataram a sede nas águas novas do Vilcanota e na última etapa voando sobre Amargosa Bahia, sobre a Gurupá e sobre o Gurupi com a sua cidade encantada, enfim toparam de novo com o mucambo ilustre do igarapé Tietê (ANDRADE, 1993, p.86).

Em Macunaíma, as metamorfoses também estão presentes no processo narrativo, pois, no seu desenrolar, a obra sofre diversas mutações, que vão da infração à norma culta à mudança de voz do narrador.

A oralidade aparece ao longo de todo texto, tanto na voz daquele que narra quanto na transcrição das falas das personagens que não detêm a cultura acadêmica, podendo ser percebida na grafia das palavras que transgride a forma dicionarizada. Termos e expressões como rapaiz, milhor e nam sculhamba são corriqueiros no livro. Também a apropriação de vocábulos regionais é feita, aparentemente, sem cuidado pelo narrador, mas denota uma tentativa evidente de romper os limites geográficos existentes dentro do Brasil: 'piá', 'querência' e 'pajelaça' são alguns dos que aparecem inseridos na narrativa, sem que haja uma referência direta aos Estados onde são coloquiais.

Mário de Andrade mostra a variedade cultural como uma extensão geográfica, fazendo com que tenhamos a consciência de que não habitamos apenas Estados, mas uma nação, possuidora de uma cultura formada a partir das expressões particulares, regionais ${ }^{10}$. A presença, ao longo da obra, das diferentes lendas brasileiras ilustra esse aspecto, porque não há uma preocupação do narrador em situá-las dentro do espaço para o leitor; ao contrário, existe a intenção de misturá-las:

\footnotetext{
${ }^{10}$ Segundo Massaud Moisés (1998), “o ser nacional residiria justamente nessa diversidade, não em qualquer das suas expressões em particular, sendo possível compreender então um dos significados do subtítulo da obra: 'herói sem nenhum caráter'”.
} 
Uma feita em que deitara numa sombra enquanto esperava os manos pescando, o Negrinho do Pastoreio pra quem Macunaíma rezava diariamente, se apiedou do panema e resolveu ajudá-lo. Mandou o passarinho uirapuru. Quando sinão quando o herói escutou um tatalar inquieto e o passarinho uirapuru pousou no joelho dele (ANDRADE, 1993, p.27).

A intertextualidade não está só presente na utilização do folclore brasileiro, mas aparece como um recurso que marca a cultura do povo, e que é modificada por ele. Os diversos textos, ao serem referidos pelas personagens, são modificados com freqüência. $\mathrm{O}$ Padre-Nosso sofre alterações que lhe tiram o caráter religioso, cristão, e ganha cunho profano, o oposto da proposta salvadora primordial, uma vez que é rezado por Macunaíma, numa macumba, com a invocação do orixá guerreiro Exu, tendo o propósito de se vingar de Venceslau Pietro Pietra:

Tia Ciata veio maneira e principiou rezando a reza maior do diabo. Era a reza sacrílega entre todas, que se errando uma palavra dá morte, a reza do Padre Nosso Exu, e era assim:

- Padre Exu achado nosso que vós estais no trezeno inferno da esquerda de baixo, nóis te quereremo muito, nóis tudo!

- Quereremos! Quereremos!

- ...O pai nosso Exu de cada dia nos dai hoje, seja feita vossa vontade assim também no terreiro da sanzala que pertence pro nosso padre Exu, por todo o sempre que assim seja, amém!...

- Glória pra pátria jeje de Exu!

- Glória pro fio de Exu! (ANDRADE, 1993, p. 51).

As transformações feitas pela oralidade têm a função de mostrar a aquisição do falar pelo povo, e também de ilustrar a evolução que a língua sofre com o passar do tempo; um desenvolvimento que ocorre espontaneamente e que acaba incorporado ao idioma, modificando-o. Tais aspectos aparecem quando, por exemplo, uma palavra - puíto -, com o sentido reinventado indiretamente pelo protagonista, é assimilada pela população que passa a usá-la no seu dia-a-dia,

Mas o caso é que "puíto" já entrara pras revistas estudando com muita ciência os idiomas escrito e falado e já estava mais que assente que pelas leis de catalepse elipse síncope metonímia metafonia metátese próclise prótese aférese apócope haplologia etimologia popular, todas essas leis, a palavra "botoeira" viera a dar em "puíto", por meio duma palavra intermediária, a voz latina "rabanitius" (botoeira-rabanitius-puíto), sendo que rabanitius embora não encontrada nos documentos medievais, afirmaram os doutos que na certa existira $\mathrm{e}$ fora corrente no sermo vulgaris (ANDRADE, 1993, p.71).

ou quando Macunaíma, falando uma série de palavras em código cifrado, em tupi-guarani "Tetápe, dzónanei pemonéite hêhê zeténe netaíte" (ANDRADE, 1993, p.77) -, provoca um efeito cômico, o que indica a possibilidade de brincarmos com as palavras.

No exemplo de puíto, por meio do narrador, percebemos a crítica de Mário de Andrade à Academia na qual explicita a necessidade da instituição em legitimar, ainda que por meio de um contorcionismo teórico, os conhecimentos lingüísticos do povo. A seriedade 
com que os doutores são vistos também é passível de ironia, pois as pesquisas e as explicações que provêm desse meio são colocadas em xeque.

Inserida no meio da narrativa, a "Carta pra icamiabas" quebra a presença dominante da oralidade, por ser um texto escrito que sofre de hipercorreção - um vício das pessoas que assimilam erradamente a língua do dominador -, ao mesmo tempo em que é um deboche escrachado à assimilação do idioma escrito/culto pela população semi-alfabetizada e à formação da língua ${ }^{11}$. Percebemos isso em pequenos detalhes da Carta, como nos erros ortográficos e de acentuação: 'imperator', 'importáncia', 'Cámbio'.

No início da missiva, o modelo utilizado é o das crônicas de viagens dos primeiros comentadores da terra brasileira. Essa apropriação gera a desconstrução dos textos. É uma paródia aos vários discursos que, ao se misturarem, perdem o valor que lhes foi legado pela intelectualidade, tornando-se uma retórica falsa, indicativa do vício do verbalismo e da eloqüência ${ }^{12}$. A Carta, o oposto ao relato oral, é uma metamorfose dentro do processo narrativo do texto, que deixa de apresentar uma fala popular para mostrar a repetição dos artifícios retóricos da linguagem dos mestres na arte da persuasão.

O narrador também é um elemento que sofre metamorfoses. Durante os relatos que contam algumas metamorfoses, como a do Pai do Mutum ou do automóvel, Macunaíma age como um rapsodo - dirige-se a um público, conta o que deseja e encerra sua narrativa de modo a não ser contestado:

- No tempo de dantes, moços, o automóvel não era uma máquina que nem hoje não, era a onça parda. Se chamava Palauá e parava no grande mato Fulano. [...]

Dizem que mais tarde a onça pariu uma ninhada enorme. Teve filhos e filhas. Uns machos outros fêmeas. Por isso que a gente fala "um forde" e fala "uma chevrolé"...

Tem mais não ( ANDRADE, 1993, p.101-103. Grifo nosso).

No início da narrativa e na maior parte dela, porém, o papel de rapsodo cabe a um contador que relata os acontecimentos; uma postura que só é percebida claramente no epílogo, quando ele se apresenta ao leitor. É aí que temos a revelação de que toda a obra é uma grande história contada oralmente, cujo narrador tem a mesma postura narrativa do herói: há um público, ao qual se dirige, encerrando seu relato de forma incontestável e utilizando fórmulas

\footnotetext{
${ }^{11}$ Eneida Maria de Souza (1999, p. 122) alega que a suspensão das ações através da inserção da carta no meio da narrativa funciona como um "questionamento da defasagem entre a língua escrita e falada e pela sátira aos defensores do culto à retórica e ao modelo lingüístico português". Ver também o capítulo "Alguns custos da radicalidade", escrito por Luís Augusto Fischer, pertencente ao livro O romance modernista.

12 Para Eneida Souza (1999, p. 128-129), a apropriação das crônicas de viagens aponta para uma "retórica artificial e inútil dos costumes [...] ao mesmo tempo em que mascara e desvela em tom humorístico a ideologia das crônicas de viagens". Ainda para a autora, a Carta tem papel de "folclorizar a retórica, resultando no efeito parodístico obtido pela articulação intertextual de múltiplos fragmentos textuais, colhidos de várias fontes".
} 
da tradição popular oral: "Acabou-se a história e morreu a vitória. [...] Tem mais não" (ANDRADE, 1993, p.134-135).

Esse narrador assume o papel de compilador e inventor. É produto de um determinado contexto - tempo e lugar - apesar de lidar com um material situado no passado - o mito indígena, as lendas, os textos da tradição européia. Ele é um homem, um eu que apresenta um olhar crítico sobre os fatos, ao contrário da personagem central ${ }^{13}$ :

Tudo ele [o papagaio] contou pro homem e depois abriu asa rumo de Lisboa. E o homem sou eu, minha gente, e eu fiquei pra vos contar a história. Por isso que vim aqui. Me acocorei em riba destas folhas, catei meus carrapatos, ponteei na violinha e em toque rasgado botei a boca no mundo cantando na fala impura as frases e os casos de Macunaíma, herói de nossa gente (ANDRADE, 1993, p. 135. Grifos nossos).

Entretanto, conforme lemos no fragmento acima, esse rapsodo não tomou conhecimento das aventuras de Macunaíma pela própria personagem, mas por intermédio de um papagaio que as ouviu da boca do protagonista e as contou ao homem. Há, desse modo, um diálogo entre narradores-rapsodos - uma troca de posições entre o narrador na terceira pessoa, Macunaíma e o papagaio, além de um narrador anônimo que aparece na primeira pessoa e no final do livro ${ }^{14}$ - no qual suas vozes se cruzam e contam a história do herói. A posição do narrador em terceira pessoa também se altera no final da obra, pois assume o papel de ouvinte e não mais de contador ao escutar a narração da ave.

Por ser uma história relatada de forma oral, há construções sintáticas que, se vistas como erros enquanto pertencentes ao texto escrito, passam a não apenas serem aceitas, mas consideradas coerentes à rapsódia. As expressões populares, geralmente rechaçadas do português culto, aqui são usadas despreocupadamente: "Macunaíma ficou de azeite uma semana, sem comer sem brincar sem dormir só porque desejava saber as línguas da terra. [...] Afinal chegou o domingo pé-de-cachimbo [...]" (ANDRADE, 1993, p.70).

Ao longo de Macunaíma, o autor não utiliza nenhum material inédito, mas lendas, tradições e falares populares. Todavia, a maneira como trata e apresenta esse mesmo material lhe dá uma aparência inédita, não apenas dentro da obra, mas dentro da literatura brasileira. $\mathrm{O}$ texto, ao usar mais de uma forma de discurso, o cruzamento de narradores, o falar popular e culto - ainda que deformado -, provoca uma renovação do fazer narrativo praticado no País. Mario de Andrade mostra que a cultura brasileira ainda não foi trabalhada suficientemente e

\footnotetext{
${ }^{13}$ Maria Augusta Fonseca (1999).

${ }^{14}$ Cf. Eneida Maria de Souza, 1999, p. 158.
} 
que o povo, se quiser se conhecer, não poderá ignorá-la, devendo (re)pensar o que entende por ela e seus elementos.

Quanto à trajetória de Macunaíma, ao mesmo tempo que "desconstrói os esteriótipos fundados na existência de uma essência brasileira" ${ }^{15}$, (re)formula a identidade nacional, pois o herói é sem caráter por conter virtudes e defeitos, características híbridas pertencentes às três etnias formadoras da nação, conhecimento do mundo primitivo e civilizado, sem se decidir por nenhum deles, mas por aglutiná-los e utilizá-los indistintamente. Precisamos considerar ainda que para entender a proposta de reformulação da identidade nacional, sugerida por Mario de Andrade, é necessário compreendê-la a partir de Macunaíma porque é pela forma narrativa que se manifesta a identidade ${ }^{16}$. É narrando as metamorfoses pelas quais passou, que causou ou que lhe foram contadas - e que dizem respeito não apenas às personagens, mas também à terra - que Macunaíma se define e, por extensão, define o povo brasileiro ao ser considerado seu herói.

Sintonizada com o Modernismo, a obra aborda a questão da identidade nacional como estando em processo de elaboração e não como já pronta e inalterável. Por isso, tal como representado da narrativa, a identidade pode ser influenciada por culturas de territórios diversos, fazendo com que aquelas assimiladas participem da composição da essência brasileira.

\section{Referências:}

ANDRADE, Mário de. Macunaíma o herói sem nenhum caráter. Belo Horizonte: Vila Rica, 1993.

ANDRADE, Oswald de. "Manifesto Antropófago". In: TELES, Gilberto Mendonça. Vanguarda européia e modernismo brasileiro. Petrópolis: Vozes, 1976, p. 293-300

BERND, Zilá. Função desacralizadora da literatura. In:_. Literatura e identidade nacional. Porto Alegre: da Universidade, 1992.

CAMPOS, Haroldo. A situação inicial. In:__. Morfologia do Macunaíma. São Paulo: Perspectiva, 1973.

CASCUDO, Câmera. Dicionário do folclore brasileiro. Rio de Janeiro: Ediouro, 1998.

\footnotetext{
${ }^{15}$ Cf. BERND, Zilá, 1992, p. 47-50.

${ }^{16}$ Cf. RICOEUR, Paul, 1985, p. 432
} 
FISCHER, Luís Augusto. Alguns custos da radicalidade: o romance modernista no Brasil. In: DACANAL, José Hildebrando (Org.). O romance modernista. Porto Alegre: da Universidade/UFRGS, 1990.

FONSECA, Maria Augusta. Macunaíma: Arlequinal ladino/latino. In: Colóquio Letras. Lisboa. n. 149-150. jul-dez. 1999.

GLISSANT, Edouard. La poétique de la relation. Le discours antillais. Paris: Seuil, 1981.

GRANDE ENCICLOPÉDIA LAROUSSE. São Paulo: Nova Cultural, 1995.

MOISÉS, Massaud. Macunaíma e a questão do nacionalismo. In: Colóquio Letras, n. 149150, jul-dez, 1998. Lisboa.

RICOEUR, Paul. Tempo e narrativa. Rio de Janeiro: Papirus, 1997. v. III.

SOUZA, Eneida Maria de. A pedra mágica do discurso. 2. ed. rev. amp. Belo Horizonte: Ed. UFMG, 1999.

ZILBERMAN, Regina. Mito e literatura brasileira. In: FLORES, Moacyr (Org.). Negros e índios: história e literatura. Porto Alegre: EDIPUCRS, 1994, p. 115-133. 